\title{
Research on Cross-border E-commerce and Financial Services Supervision
}

\author{
Xin Sun \\ No. 99 Shangda Road, Baoshan District, Shanghai, China \\ Sunxin.joe@qq.com
}

\begin{abstract}
Keywords: Cross-border e-commerce; Financial services supervision; Dilemma; Policy recommendations
\end{abstract}

\begin{abstract}
This paper starts from the development history and current situation of cross-border e-commerce and financial service supervision, and expounds the connotation and main content of cross-border e-commerce and financial service supervision. By analyzing the shortcomings and difficulties of the two in the process of development and evolution, the article finally gives relevant solutions and policy recommendations.
\end{abstract}

\section{Research Background}

E-Commerce originated from IBM. In 1996, the company proposed the concept of E-Commerce. It believed that E-Commerce is an information-based means used by enterprises and their business objects at all stages of the trade process. The definition of e-commerce by the United Nations International Trade Facilitation Simplification Working Group also adopts this basic connotation. China's Ministry of Commerce "Twelfth Five-Year" e-commerce development guidance Opinions, the e-commerce service platform, credit protection, electronic payment, logistics and electronic certification as the main content of e-commerce service industry development.

For cross-border e-commerce in the advanced form of e-commerce, Chinese scholars and institutions have conducted extensive research. Zhou Jialu (2013) believes that cross-border e-commerce refers to international trade that is formed through e-commerce platforms and delivered through cross-border logistics. Laiwei and Wang Kaiqian (2015), Ouyang Xiaobo (2014), Wang Xingping (2013) and other believe that cross-border e-commerce is an international trade through customs through Internet mail or express delivery.

The above definition of cross-border e-commerce is not comprehensive enough. The first view does not mention the intangible cross-border e-commerce trade completed by Internet mail, telephone, etc., nor the gray situation such as Haitao and Haidai; the second view considers intangible international trade, but also Gray is not considered. Whether it is intangible or gray cross-border e-commerce trade, it is inseparable from financial services supervision such as exchange and payment clearing. Therefore, this paper defines cross-border e-commerce and financial supervision services, and defines cross-border e-commerce as: the participating entities complete product display and negotiation with one or more information means such as e-commerce platform, Internet mail or mobile terminal. Part or all of the payment, exchange, etc., and finally the transfer of the cross-physical borders of the capital goods.

The development history and current situation of cross-border e-commerce and financial service supervision in China. In recent years, China's cross-border e-commerce has developed rapidly, and the transaction volume has expanded from 1.3 trillion yuan in 2010 to 5.2 trillion yuan in 2015; the proportion of China's import and export trade has gradually increased, from $6.3 \%$ in 2010. Increased to $17.6 \%$ in 2015. According to the forecast of the Ministry of Commerce, the proportion of cross-border e-commerce in China's import and export trade will increase to $20 \%$ in the next few years, and the annual growth rate will exceed $30 \%$. The cities that have launched cross-border e-commerce pilot projects have gradually expanded from the first five cities in Shanghai, Chongqing, Hangzhou, Ningbo and Zhengzhou in 2012 to 14 cities in 2015. At the same time, the rapid development of service providers that provide payment and settlement for 
cross-border e-commerce has prompted e-commerce to realize the integration of online offline settlement transactions to online display settlement transactions. At present, there are two main ways of payment settlement services: one is the payment by non-financial institutions. This category can be divided into two situations, one is the payment platform for self-built or acquired e-commerce platform. The other is a separate third-party payment agency. Second, financial institutions pay, usually by means of e-banking, telephone banking or mobile banking. China's cross-border e-commerce and the development of financial services supervision such as payment settlement, exchange, etc., can be divided into three stages according to the landmark events in its development process.

Introduction and start-up phase. In the late 1990s, domestic e-commerce websites such as Alibaba and Joyo.com were found to be profitable. Some governments and enterprises began to try to combine e-commerce with foreign trade. In July 1998, the Ministry of Foreign Trade and Economic Cooperation opened the "China Commodity Market" on its official website for the display and promotion of products by Chinese enterprises, which attracted the attention of domestic and foreign merchants and promoted a number of foreign trade. In October 2000, Alibaba launched the "China Supplier" service to help Chinese companies expand their export trade. In December 2001, China Chemical Network and Germany's Buyersguidechem platform cooperated to form a cross-border trading platform to open the era of cross-border e-commerce in China. At this stage, cross-border payment was solved by cooperating with foreign banks to share accounts.

Rapid growth stage. Trade protectionism rose after the 2008 financial crisis. According to statistics, from November 2008 to May 2013, 3334 trade protection measures were implemented worldwide. At the same time, regional economic cooperation negotiations such as the TPP (Trans-Pacific Partnership Agreement) and BIT (Bilateral Investment Agreement) have continued to heat up. Under this situation, in March 2012, the Ministry of Commerce issued the "Several Opinions on the Use of E-Commerce Platforms for Foreign Trade" to encourage enterprises to conduct cross-border e-commerce. In May of the same year, the National Development and Reform Commission issued the "Development of National E-Commerce Demonstration". The Notice of Special Projects for Urban E-Commerce Pilots, piloting cross-border e-commerce services as a key pilot area, and approved five cities including Shanghai, Chongqing, Hangzhou, Ningbo and Zhengzhou as the first pilot projects. Cross-border e-commerce has ushered in development opportunities, and it has also been accompanied by financial services supervision.

High-speed development stage. Since 2015, China's economy has entered a new normal, and the atmosphere of "Internet +" and "mass entrepreneurship and innovation" has become more and more important. The government attaches more and more importance to cross-border e-commerce, especially in January 2016, the State Council decided to be active and secure. We will expand the pilot program for cross-border e-commerce, replicate and promote the construction of six major systems in the new cross-border e-commerce comprehensive pilot zone, and build experience in the online "single window" and offline "integrated park" platforms. During this period, the commercial cross-border e-commerce platform has successively launched Netease's "Koala Sea Purchase", SF Express SF Haitao, and "Jingdong Global Purchase"; the government-led cross-border e-commerce platform has 2015 Shandong Province. 8 cross-border e-commerce industry gathering areas such as Chengxian Hair Products Industrial Park and the "Shanghai Cross-border E-commerce Demonstration Park" launched in March 2016.

Main Contents of Cross-Border E-Commerce and Financial Service Supervision in China. In the field of financial supervision, rule-oriented supervision and principle- oriented supervision are the two main modes of consideration. Rule regulation is operative and has no flexibility by formulating specific rules. China's finance has always been a typical rule-oriented supervision, which is reflected in the accounts, payments, and foreign exchange payments related to e-commerce, especially in the case of transactions and exchanges in cross-border trade, which are managed by the competent departments of operations and the State Administration of Foreign Exchange. In addition, due to historical reasons and the implementation of the foreign exchange settlement and 
sales system over a period of time, China has formed a huge foreign exchange reserve with US dollars as the mainstay and multiple international currencies coexisting. There are two main views on the excessive foreign exchange reserves of developing countries: one is that starting from the new mercantilism, the reserve foreign exchange is considered to meet the trading needs, represented by McKinnon, Krugman, etc.; The view is that reserve foreign exchange is a compulsory prevention requirement, represented by Ben-Bassat and Gottlieb (1992), Aizenman and Marion (2004). From a practical point of view, it is more appropriate to combine the two viewpoints to explain the current situation of China's foreign exchange. At the same time, the management ideas for the settlement and sale of foreign exchange still exist in the current foreign exchange operation.

\section{The Dilemma between China's Cross-Border E-Commerce and Financial Services Supervision}

There is a certain gap between foreign exchange quota management and cross-border e-commerce demand. First, some corporate individuals do not use settlement accounts. At present, many cross-border e-commerce platforms are registered with personal identification numbers instead of institutions. The detailed rules for the implementation of the personal foreign exchange management regulations stipulate that the foreign exchange receipts and expenditures of the foreign trade operators and the international balance of payments declarations shall be managed by the institution, and the individual industrial and commercial households may handle the collection and payment of foreign exchange through their foreign exchange settlement accounts, which does not occupy the quota. In fact, some enterprises or individuals that carry out e-commerce have not handled the list of import and export enterprises of the foreign exchange bureaus due to various reasons such as Haidai and Haitao. Although they have a real trading background, they cannot use foreign exchange payment settlement accounts and can only use foreign exchange savings accounts. This is the annual total. When the group's personal foreign exchange savings account exceeds the annual total management of 50,000 US dollars per person, often with the help of other people's account operations, there are policy risks such as split operations. Second, the domestic payment institutions that enjoy the policy dividends have a low market share in foreign markets. Huifa [2015] No. 7 clarifies that the personal settlement and sale of foreign exchange under the cross-border foreign exchange payment business of the payment institution is not included in the total annual foreign exchange settlement and sales. The payment institution here refers to the domestic third-party payment institution that has obtained the business license of the People's Bank of China and has handled the "List of Foreign Exchange Income and Expenditure of Goods Trade" according to the regulations on foreign exchange administration. However, at present, China's cross-border third-party payment market is mainly monopolized by overseas companies such as PAYPAL in the United States. If it is paid overseas by overseas payment agencies, it is still subject to annual total restrictions.

The cross-border RMB settlement system started relatively late and the function has yet to be improved. The launch of CIPS (RMB Cross-Border Payment System) on October 8, 2015 provided a channel for RMB cross-border payment settlement, but there is still a gap compared with the well-known SWIFT. First, the service time is relatively short. Currently CIPS is 19:00 20:00 and SWIFT is 21 hours. Second, the coverage is relatively narrow. The direct participants of the CIPS system are 19 domestic and foreign banks, 307 indirect participants, covering 47 countries and regions; and SWIFT serves more than 11,000 banks, securities and enterprises in more than 200 countries and regions, providing services to 1,700 financial institutions. RMB trading. Third, the function list is relatively thin. CIPS is mainly for RMB settlement, remittance and investment and financing. It also needs to coexist with the agency and clearing bank models for a relatively long period of time. In addition to the above functions, SWIFT also provides financial message services and credit financing. Fourth, independence needs to be strengthened. In March 2016, CIPS and SWIFT signed a Memorandum of Cooperation, proposing to connect its global user community to CIPS through SWIFT network and financial messaging services. 
The loan channel is relatively abundant, but the financing problem still exists. Relative to ordinary corporate loans, due to the characteristics of e-commerce enterprise network transactions, settlement and other data, its loan channels are more broad, but they have many restrictions. Traditional banks have also increased their online sales data applications. ICBC and Bank of China have introduced small loans for small businesses and small micro-network customers. However, the problem of corporate financing still exists, and the non-bank loans have problems such as low quota and small scope. Bank loans are subject to constraints such as insufficient guarantees for effective collateral of e-commerce enterprises, limited scope of collateral, and small demand for funds. The loan is limited.

Third-party payment institutions are not well developed and international influence is insufficient. Third-party payment agencies play an active role in cross-border e-commerce. According to statistics, in 2014, the total amount of online payment services generated by national payment institutions was 24.72 trillion yuan, a year-on-year increase of $137.6 \%$. However, due to the significant Matthew effect in the industry, the first-mover advantage is obvious, showing a situation of uneven development. First, the development of domestic institutions is uneven. Among the 117 Internet payment institutions in 2015, the top 6 (Alipay, Tenpay, UnionPay, Fast Money, Remittance, Epro) market share was 93.7\%. Second, regional development is uneven. Jiangsu, Shanghai, Shenzhen and other third-party payment institutions have also developed fast-growing places to attract talents and e-commerce companies through the introduction of support policies or the establishment of special funds. Third, the development of the two markets at home and abroad is not balanced, and the payment institutions such as Alipay and WeChat, which have a high domestic market share, are not highly recognized abroad. Fourth, information transparency is not high. Due to the professionalism and commercial confidentiality of third-party organizations, consumers are not aware of details such as fund management and technical security. In the absence of third-party evaluation, consumers can only rely on business licenses, business licenses and other aspects to determine the possibility of self-interest violations.

There are certain difficulties in the supervision of payment institutions. First, the adaptability of the regulatory system is insufficient. The policy is aimed at non-financial institutions. Most of the payment services are compliant special regulatory provisions, lacking quantitative and comprehensive evaluation indicators. At the same time, for financial innovations such as QR code payment and virtual credit card, traditional financial supervision system It has not been covered, and only the administrative law enforcement department can adopt the "suspended" method afterwards. Second, the regulatory authority is not enough. There are not many rules and regulations for e-commerce payment supervision. For example, the supervision and management of electronic payment, which is the core content of e-commerce, is currently at the legal level and has not yet reached the legal level. Third, the regulatory model is misaligned with the actual situation. At present, the services provided by non-financial payment institutions on their payment platforms often integrate banking, insurance, securities and other aspects, providing comprehensive services such as wealth management, fund raising, fund custody, and online loans. At present, the current situation of China's financial sector supervision is in conflict, and it is prone to long-term management or short-term management, which may cause local financial instability.

\section{Suggestions on Cracking the Dilemma of Cross-Border E-Commerce and Financial Services Supervision}

Improve the fit of cross-border e-commerce foreign exchange demand and management. The first is to further clarify the scope of cross-border e-commerce, break through the restrictions of cross-border e-commerce goods trade and some service trade transactions, and clarify intangible goods with controllable risks, and increase virtual products such as online games. The second is to improve the personal foreign exchange business monitoring system, add a new type of "cross-border e-commerce" in the foreign exchange business monitoring system and properly supervise it. Facilitating personal identity for cross-border e-commerce is not limited to the annual total limit. The third is to clarify the definition of institutions and individuals, to clarify the 
conditions for opening accounts of individual foreign trade operators and individual industrial and commercial households lacking the organization code, and to guide financial institutions to increase the audit of the authenticity of e-commerce platforms and payment institutions to protect registration information. Consistent with merchants to ensure a real trading background.

Strengthen financial innovation and continuously expand corporate financing channels. The first is innovative loan services and products. In order to address the Internet attributes of e-commerce enterprises, intangible assets and movable property pledge financing should be carried out on the basis of risk control; financial products such as cash flow, consumer loans, supply chains and third-party fund custody will be provided based on electronic data such as cash flow and UnionPay. Financial services such as financial leasing; for major projects in e-commerce parks or e-commerce enterprises, increase credit support by means of syndicated loans and direct loans from the head office. The second is to explore ways to improve corporate credit financing. For e-commerce enterprises that meet the needs of Internet transactions, actively carry out pilot work on performance-guarantee insurance business and other insurance models; explore ways and strengths of export credit insurance for e-commerce enterprises; and play a government-based (policy) financing guarantee institution in electronics The role of guarantee and credit enhancement in business enterprise financing reduces the financing cost of enterprises.

Strengthen cross-border payment norm development and brand building. The first is to improve the system guarantee of supervision and inspection. Clear operational rules such as anti-money laundering, consumer protection, reserve fund management, and corporate bankruptcy to improve regulatory operability. Gradually increase the good practice and good experience to the legal level, pay attention to the connection with criminal law, civil law and commercial law, and improve the effectiveness of supervision services. The second is to strengthen the construction of external evaluation mechanisms. Give full play to the self-discipline role of industry associations, make good use of third-party evaluations such as the People's Bank of China Credit Information System, Netcom Credit Information Co., Ltd., and gradually create a market atmosphere of reward and trustworthiness, disciplinary and dishonesty. The third is to strengthen the management of payment institutions. Strengthen the risk management of the industry, especially the management of client funds and reserve funds of third-party payment institutions, to avoid the occurrence of untimely payment and difficulties in payment due to poor business management and ethics.

\section{References}

[1] J.W. Zhou: Analysis and Suggestions on the Status Quo of Cross-border E-commerce in China[J]. China Business Review, 2013(34).

[2] Y.W. Lai, K.Q. Wang: China's cross-border e-commerce development pattern, obstacles and its next step[J]. Reform, 2014(5): 68-74.

[3] X.B. Ouyang: Status Quo and Suggestions of Cross-border E-commerce Development[J]. Chinese and Foreign Entrepreneurs, 2014(11): 42-44.

[4] X.P. Wang: Exploring the Rapid Development of Cross-border E-commerce and Third-Party Payment Management[J]. Regional Finance Research, 2013(12): 67-70.

[5] A. Ben-Bassat, D. Gottlieb: Optimal international reserves and sovereign risk [J]. Journal of International Economics, 2004, 33(3-4): 345-362.

[6] J. Aizenman, N. Marion: International Reserve Holdings with Sovereign Risk and Costly Tax Collection *[J]. Economic Journal, 2004, 114(497): 569-591.

[7] Ran. Feng: Research on China's Cross-border E-commerce Tariff Supervision[J]. International Economics and Trade Research, 2015(2): 77-85. 